\title{
Dietary effects on the secretion and actions of growth hormone
}

\author{
By M. R. Turner, Department of Physiology and Biochemistry, University of \\ Southampton, Southampton $\mathrm{SO}_{9}{ }_{5} \mathrm{NH}$
}

\section{Introduction}

The stimulation by growth hormone $(\mathrm{GH})$ of food intake and growth has been discussed fully elsewhere (Cheek, 1968). Many aspects of the structure, secretion and actions of the hormone are described in Pecile \& Müller (1968, 1972), and a consideration of nutritional and hormonal influences on mammalian protein metabolism has been given by Munro (1970).

Besides stimulating protein synthesis and cell division (Cheek \& Hill, I970), GH plays an important part in the continuous regulation of protein and energy metabolism by stimulating protein synthesis, lipolysis and glucose conservation. The lipolytic action may result from an initial stimulation of protein synthesis (Fain, Kovacev \& Scow, 1965) and by means of the 'glucose-fatty acid cycle' (Randle, Garland, Hales, Newsholme, Denton \& Pogson, 1966) may lead to the glucose conservation reported by Russell (195I),

The concept of diet affecting the secretion and action of hormones is far from new. Peripheral glucose uptake is reduced by low-carbohydrate diets (Aldersberg \& Porges, I926; Hales \& Randle, r963), which could result from reduced insulin secretion or, as Himsworth (1935) suggested, from reduced tissue sensitivity to insulin, a process which is substantially influenced by GH (Glick, Roth, Yalow \& Berson, r $96_{5}$; Daughaday $\&$ Kipnis, I966). The consumption of high-carbohydratelow-protein diets is also associated with impairment of peripheral glucose uptake (Bowie, 1964; Heard, Turner \& Platt, 1964) and this is related more to tissue responsiveness to insulin than to circulating levcls of the hormone (Heard \& Turner, I967; Heard \& Henry, I969). When a severely protein-deficient diet was fed to pigs from I week of age indirect evidence indicated reduced GH activity (Heard, 1966), which is in keeping with the idea of a nutritionally induced pseudohypophysectomy suggested by Mulinos \& Pomerantz (1940). Food intake was below normal in those pigs. On the other hand, when moderately protein deficient-high carbohydrate diets were fed to dogs from the normal weaning age of 6 weeks and eaten in nearly normal amounts excessive $\mathrm{GH}$ activity was the consequence (Heard \& Turner, 1967; Heard, Henry, Hartog \& Wright, I968).

Therefore the severity of the protein insufficiency, the total food intake and the age of onset of the nutritional inadequacy could have determined whether adaptation resulted in increased or decreased $\mathrm{GH}$ activity.

$3 I(2) 9$ 


\section{GH secretion}

Kwashiorkor and marasmus are two extreme types of protein-calorie malnutrition (PCM) and between these extremes lies a spectrum of nutritional disorder. In infants suffering from kwashiorkor, which usually results from eating a low-protein diet in generous amounts after a prolonged suckling period of $I-2$ years, and which may be precipitated by infection or infestation, the fasting plasma GH concentration is raised from about $7 \mathrm{ng} / \mathrm{ml}$ to about $25 \mathrm{ng} / \mathrm{ml}$ (Pimstone, Barbezat, Hansen \& Murray, I968; Beas, Contreras, Maccioni \& Arenas, 1971). In marasmus, which is usually the consequence of eating insufficient food from an early age, the same may be true (Pimstone et al. I968; Milner, 197I), but severe marasmus in Chile is associated with a significant reduction in the fasting plasma GH concentration to $4 \mathrm{ng} / \mathrm{ml}$ (Beas et al. I97I). In contrast to malnourished infants in other parts of the world, who usually respond to dietary therapy, albeit with difficulty, the severe marasmic infants in Chile only grew in response to combined dietary and human GH therapy (Mönckeberg, Donoso, Oxman, Pak \& Meneghello, I963) and, as discussed by Waterlow \& Alleyne (I97I), they might be described more accurately as nutritional dwarfs. By adapting to an adverse nutritional environment with reduced pituitary function and hence growth, their nutrient requirements would be decreased. In addition to a low concentration of plasma GH in these infants, it is tentatively suggested that tissue responses to GH may be reduced (Mönckeberg et al. 1963), an idea put forward for kwashiorkor by Hadden \& Rutishauser (1967).

$\mathrm{GH}$ secretion is stimulated by some amino acids, notably arginine and lysine

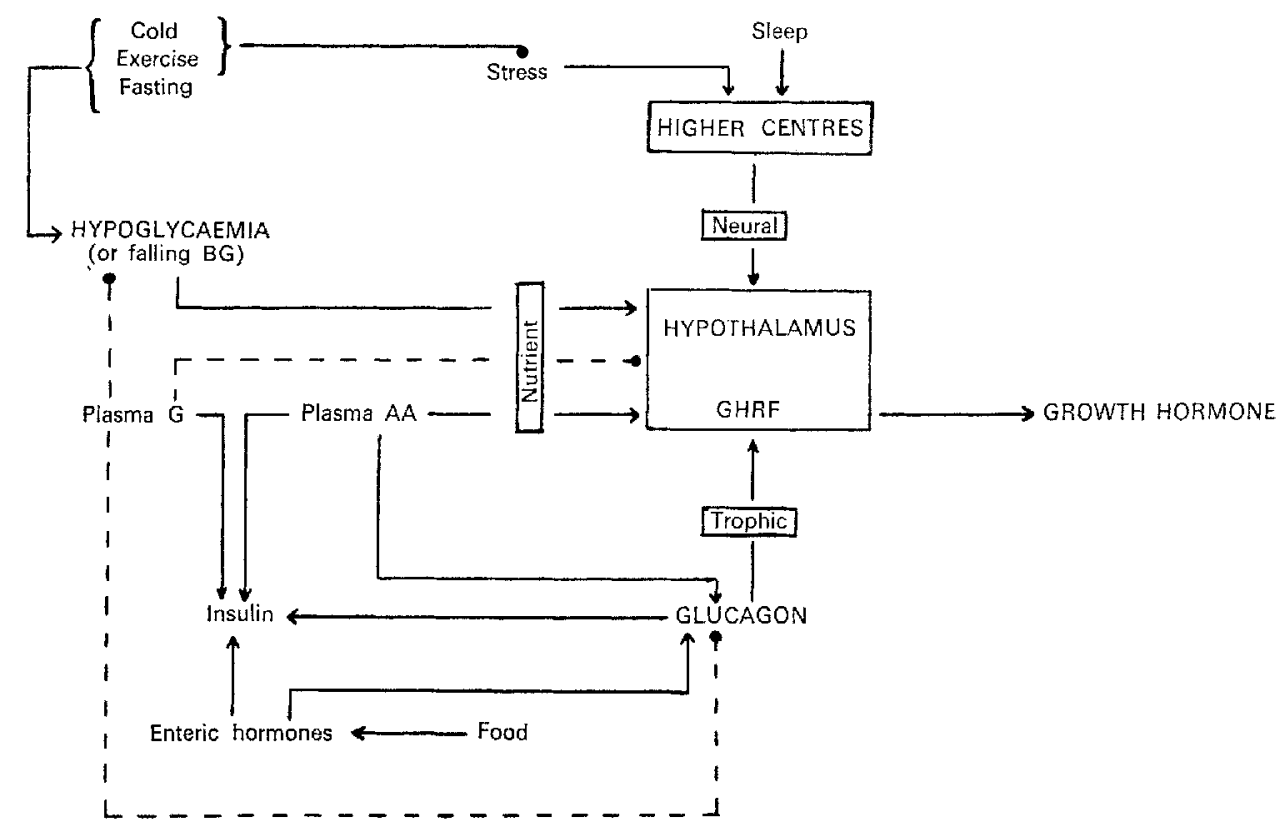

Fig. I. A scheme for the secretion of growth hormone in the normal animal. Stimulation $\longrightarrow$ inhibition - - - ; BG, blood glucose; $G$, glucose; AA, amino acids; GHRF, growth hormone releasing factor. 
(Knopf, Conn, Floyd, Fajans, Rull, Guntsche \& Thiffault, x 966) which also stimulate insulin secretion (Fajans, Floyd, Knopf \& Conn, r967), and by a falling or reduced blood glucose concentration, but secretion is suppressed by hyperglycaemia (Glick et al. 1965). A scheme for GH secretion in the normal is shown in Fig. I. In protein-calorie malnourished infants stimulation of $\mathrm{GH}$ secretion by arginine (Beas et al. 1971) and by insulin-induced hypoglycaemia (C. Godard and G. Zahnd; personal communication cited by Beas et al. $197 \mathrm{I}$ ) and normal inhibition of secretion by glucose infusion (Pimstone, Barbezat, Hansen \& Murray, 1967) do not occur.

Thus the malnourished infant has lost the ability to respond to nutrient (metabolite) signals for the stimulation and inhibition of GH release. On the other hand, Milner (197I) has suggested that the secretory response to glucagon and possibly to the stress of venepuncture is retained in the malnourished. Thus neural signals and glucagon apparently remain effective. In these observations may lie the explanation of the raised fasting plasma GH concentration in most cases of PCM.

When malnourished infants are treated with therapeutic protein-containing diets, the fasting plasma GH level is restored to normal (Pimstone et al. 1968) and the inhibitory effect of glucose infusion on GH secretion reappears (Pimstone et al. 1967). On the other hand, giving a protein-free diet isocalorically had no effect on GH levels.

During dietary therapy, malnourished infants may grow at many times the normal rate (Milner, I97I) until they achieve a more appropriate weight for height and age, but this does not seem to relate to the circulating GH level, which is falling at the time of rapid growth. In rats, 'catch-up' growth occurs only when a period of fooddeprivation is imposed after weaning, whereas food lack from an earlier age results in permanent stunting of growth (Widdowson \& McCance, r963), a situation analogous to the severe marasmus in Chile.

Therefore one could tentatively suggest that: (I) raised levels of fasting plasma GH in PCM may result from a loss of response to inhibitory metabolite (nutrient) signals, while maintaining a secretory response to neural ('stress') and glucagon stimulation; (2) growth responses may not relate to circulating levels of GH but may reflect changes in tissue responsiveness to the hormone resulting from dietary changes; and (3) the age of onset as well as the severity of the dietary insufficiency may determine whether GH activity is increased or decreased in PCM.

\section{GH actions}

GH in vivo causes a reduction in the plasma and tissue concentrations of free amino acids and an increased tissue protein content (Russell, 1951). In hypophysectomized animals GH has been shown to stimulate the movement of amino acid into muscle (reviewed by Knobil \& Hotchkiss, 1964). In muscle from hypophysectomized rats incubated in vitro, it has become accepted that GH stimulates both the incorporation of amino acid into protein (Kostyo \& Knobil, 1959; Manchester \& Young, 1959; Knobil, r 966) and the accumulation of many naturally occurring amino acids (Knobil, I966). The effect of GH on protein synthesis in muscle 
from hypophysectomized animals is not dependent on amino acid uptake (Kostyo, I964). On the other hand the uptake effect is blocked by inhibitors of protein synthesis (Hjalmarson, I968; Kostyo, I968) and is therefore dependent on de novo protein synthesis. In contrast, the stimulation of amino acid uptake by insulin is not prevented by inhibitors of protein synthesis (Wool, Castles \& Moyer, I965). The whole subject is reviewed by Manchester (I970) and Tata (I970),

More recent observations in tissues from non-hypophysectomized animals suggest that the concept of $\mathrm{GH}$ stimulating both the uptake of amino acid and its incorporation into protein may not be appropriate for the intact animal under normal physiological circumstances.

In diaphragm muscle from non-hypophysectomized rabbits, I have shown that $\mathrm{GH}(0.5 \mu \mathrm{g} / \mathrm{ml})$ will stimulate protein synthesis without having any effect on the uptake of the five amino acids studied so far, namely valine, leucine, arginine, lysine and histidine. Similar results have been obtained for valine with a GH concentration of $0.1 \mu \mathrm{g} / \mathrm{ml}$ (Reeds, Munday \& Turner, 1971). Thus as a result of the significant stimulation of the incorporation of all five amino acids, with no increase in uptake, the tissue:medium isotope distribution (T:M) ratio was reduced in each instance. This is in contrast to the action of insulin on similar preparations in which both accumulation and amino acid incorporation were stimulated, with a consequent increase in the T:M ratio (Reeds et al. 1971). The percentage of the label taken up by the muscle cells which was incorporated into protein was similar for all of the amino acids, that is about $34 \%$. This was increased to about $53 \%$ in the presence of GH but was unchanged by insulin. Stimulation by $\mathrm{GH}$ of $\left[{ }^{14} \mathrm{C}\right] l$ leucine incorporation into protein, without any effect on its rate of uptake, is reported in liver from non-hypophysectomized rats exposed to high concentrations of amino acid in the medium such as might be encountered in the portal vein (Clements \& Korner, 1970).

Therefore the role of GH in non-hypophysectomized animals may be the stimulation of cellular protein synthesis from existing amino acid pools rather than the movement of extracellular amino acid into protein, the latter being a role which seems more appropriate for insulin.

Further experiments were done with groups of rabbits fed for $5 \mathrm{~d}$ on a protein-free or a $5 \%$ casein diet, both of which were consumed in an amount similar to the food intake of control animals. Diaphragm muscle was studied as before; results for valine are given in Table $\mathrm{r}$. In the protein-deficient groups, the basal rate of amino acid incorporation into protein was reduced in most instances whereas, except for valine, the basal rate of amino acid uptake was usually similar to that of tissue from control animals. In the $5 \%$ casein group, stimulation of amino acid incorporation into protein by $\mathrm{GH}$ was impaired but, as in tissue from control animals, there was no effect of GH on amino acid uptake. In muscle from rabbits fed on the protein-free diet, on the other hand, there was a significant stimulation by GH of the uptake of all five amino acids studied, an effect which was blocked by cycloheximide $(4 \mu \mathrm{g} / \mathrm{ml})$. As a result of the increased uptake of labelled amino acid, the stimulation of amino acid incorporation by GH was greater than in the $5 \%$ casein group, but generally 
Table r. Effect of growth hormone $(G H)(0.5 \mu \mathrm{g} / \mathrm{ml})$ on the uptake and incorporation into protein of $\left[{ }^{14} \mathrm{C}\right]$ valine $\$$ in diaphragm muscle in vitro from adult non-hypophysectomized rabbits fed for 5 d on different diets

\begin{tabular}{|c|c|c|c|c|c|c|}
\hline \multirow[b]{2}{*}{$\begin{array}{l}\text { Diet } \\
\text { Control } \\
\text { Casein, } 5 \% \\
\text { Protein-free }\end{array}$} & \multicolumn{2}{|c|}{$\begin{array}{c}\text { Uptake } \\
\left.\text { (nmol/g fresh wt } \mathrm{h}^{-1}\right)\end{array}$} & \multicolumn{2}{|c|}{$\begin{array}{c}\text { Incorporation } \\
\left(\mathrm{nmol} / \mathrm{g} \text { fresh wt } \mathrm{h}^{-1}\right)\end{array}$} & \multicolumn{2}{|c|}{$\begin{array}{l}\text { Tissue; medium isotope } \\
\text { distribution ratio } \\
\text { tegrations/min per ml cell water: } \\
\text { tegrations/min per } \mathrm{ml} \text { medium) }\end{array}$} \\
\hline & $\begin{array}{l}\text { Basal } \\
74 \\
\text { soft } \\
\text { r ioft }\end{array}$ & $\begin{array}{c}\text { Change } \\
\text { after GH } \\
0 \\
+6 \cdot 2 \\
-28 \cdot 5 * \dagger\end{array}$ & $\begin{array}{l}\text { Basal } \\
20 \cdot 8 \\
9 \cdot 2 \dagger+ \\
13 \cdot 6+\dagger\end{array}$ & $\begin{array}{l}\text { Change } \\
\text { after GH } \\
+17 \cdot 6^{* *} \\
+2.5^{*}+\dagger \\
+6 \cdot 6^{*}+1\end{array}$ & $\begin{array}{l}\text { Basal } \\
I \cdot 43 \\
0.95 \dagger \\
2 \cdot 02\end{array}$ & $\begin{array}{l}\text { Change } \\
\text { after GH } \\
-0.52^{*} \\
+0.05 \dagger \\
+1.3 I^{*}+\dagger\end{array}$ \\
\hline
\end{tabular}

Significance of difference from basal due to $\mathrm{GH}: * P<0.05 ; * *<<0.0 \mathrm{r}$.

Significance of difference from rabbits given control diet: $+P<0.05 ;+\uparrow P<0.01 ;+1+P<0.001$.

tResults for leucine, arginine, lysine and histidine were generally similar; see p. 208 .

less than that in control tissue. GH caused a significant increase in the T:M ratio for all five amino acids in the protein-free group, but had no effect on the T:M ratio in the $5 \%$ casein group, and caused a significant decrease in the $T: M$ ratio in the control group (Turner, Reeds \& Munday, 197I and unpublished).

Therefore, muscle from rabbits receiving the $5 \%$ casein diet showed the type of response to GH typical of normally fed adult non-hypophysectomized rabbits. In muscle from rabbits fed on the protein-free diet the effect of $\mathrm{GH}$ was similar to that in tissues from hypophysectomized rats. The effectiveness of GH in stimulating protein-synthesis in both these protein-deficient groups was impaired.

Reduced protein synthesis such as is observed in hypophysectomized animals, pancreatectomized animals and protein-calorie malnourished animals may be corrected by the appropriate hormonal or dietary therapy. Part of the explanation for this can be found in terms of polysome formation, which is known to increase protein synthetic ability and to be stimulated by GH (Korner, 1964, 1968), insulin (Wool, Stirewalt, Kurihara, Low, Bailey $\&$ Oyer, 1968 ) and in liver, by tryptophan acting as a regulator amino acid (Pronczuk, Baliga, Triant \& Munro, i968). An analogous amino acid regulatory system may operate in muscle. However, changes in the polysome profile may account for only part of the reduction in the protein synthetic ability of rats fed on low-protein diets (Young \& Alexis, r968). A further reduction could result from poor binding to ribosomes of aminoacyl-tRNA, a process which is impaired in muscle (Kostyo \& Rillema, 1971) and liver (Barden \& Korner, 1972) ribosome systems derived from hypophysectomized animals.

In the malnourished animal there are complex changes in hormonal secretion (Milner, 1970) as well as altered cellular responses to hormoncs. Both of these changes could contribute to the altered protein synthetic activity observed and should be regarded as an adaptation to the adverse nutritional environment.

\section{Comment}

After eating, insulin secretion is stimulated and GH secretion suppressed in the normal animal (Knopf et al. 1966). As depicted in Fig. 2 the liver acts as a buffer 


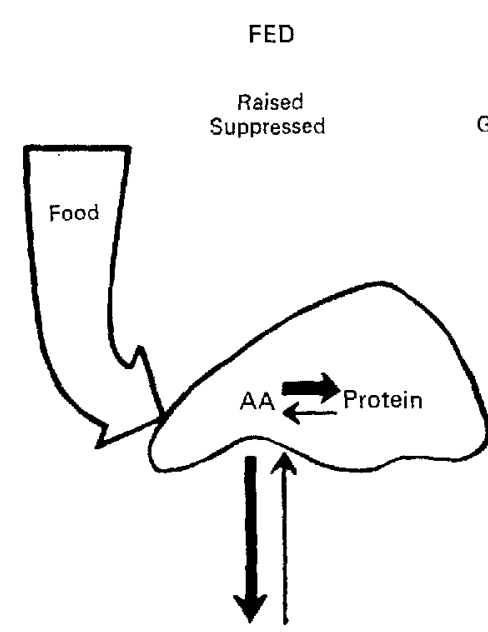

AA

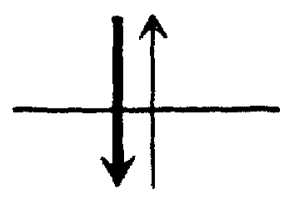

AA

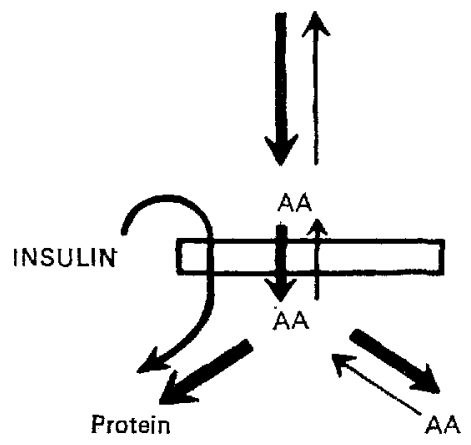

FASTED

Suppressed INSULIN
GROWTH HORMONE

LIVER

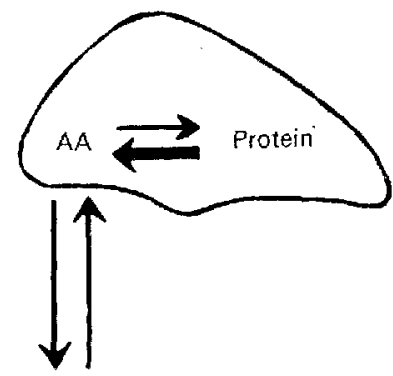

AA

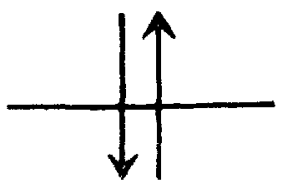

AA

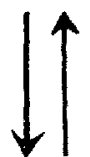

CELL MEMBRANE

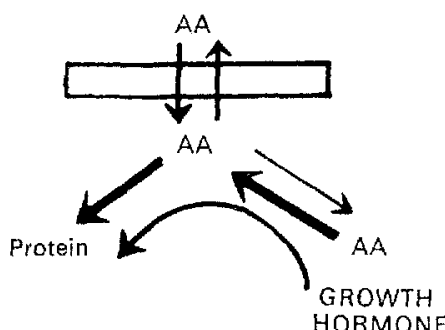

INTRACELLULAR
COMPARTMENT

(MUSCLE)

Fig. 2. Scheme for the effects of insulin and growth hormone on protein synthesis in the fed and fasted state. AA, amino acids.

against excessive changes in the amino acid content of the peripheral plasma by retaining or donating protein in the fed and fasted state. In the fed state the movement of dietary amino acid into muscle protein, the major site of amino acid deposition (Munro, r970), will be stimulated mainly by insulin. As the level of plasma GH rises under the influence of amino acid stimulation or a falling blood glucose level or both, and with increasing time after the previous meal, the ability of GH to stimulate protein synthesis at the expense of intracellular amino acid as described 
above, may become increasingly important in maintaining cellular function, despite an ever diminishing supply of substrate.

Therefore, it may be possible to attribute to $\mathrm{GH}$ in protein synthesis a role analogous to that which it is thought to perform in energy metabolism, namely protection of the organism against the adverse effects of a short-term fast.

That is the position in the well-nourished animal: in the malnourished not enough is known about hormone-tissue interactions for accurate predictions to be made about metabolic responses to circulating hormones.

\section{REFERENCES}

Aldersberg, D. \& Porges, O. (1926). Klin. Wschr. 5, I45 1.

Barden, N. \& Korner, A. (1972). Biochem. F. 127, 411.

Beas, F., Contreras, I., Maccioni, A. \& Arenas, S. (1971). Br. F. Nutr. 26, 169.

Bowie, M. D. (1964). S. Afr. med. 7. 38, 328 .

Cheek, D. B. (editor) (1968). Human Growth. Philadelphia: Lea and Febiger.

Cheek, D. B. \& Hill, D. F. (1970). Fedn Proc. Fedn Am. Socs exp. Biol. 29, 1503.

Clements, M. J. \& Korner, A. (1970). Biochem. F. 1x9, 629.

Daughaday, W. H. \& Kipnis, D. W. (1966). Recent Prog. Horm. Res. 22, 49.

Fain, J. N., Kovacev, V. P. \& Scow, R. O. (1965). F. biol. Chem. 240, 3522.

Fajans, S. S., Floyd, J. C. Jr, Knopf, R. F. \& Conn, J. W. (1967). Recent Prog. Horm. Res. $23,617$.

Glick, S. M., Roth, J., Yalow, R. S. \& Berson, S. A. (1965). Recent Prog. Horm. Res. 2r, $24 \mathrm{x}$.

Hadden, D. R. \& Rutishauser, I. H. E. (1967). Archs Dis. Childh. 42, 29.

Hales, C. N. \& Randle, P. J. (I963). Lancet i, 790.

Heard, C. R. C. (1966). Diabetes $\mathbf{5}_{5}, 78$.

Heard, C. R. C. \& Henry, P. A. J. (r969). Clin. Sci. 37, 37.

Heard, C.R.C., Henry, P. A. J., Hartog, M. \& Wright, A. D. (1968). Proc. Nutr. Soc, 27, 6 A.

Heard, C. R. C. \& Turner, M. R. (r967). Diabetes $16,96$.

Heard, C. R. C., Turner, M. R. \& Platt, B. S. (rg64). Proc. Nutr. Soc. 23, vi.

Himsworth, H. P. (1935). Clin. Sci. 2, 67 .

Hjalmarson, A. (1968). Acta endocr, Copenh. 57, Suppl. no. I26 p. 37.

Knobil, E. (1 966). Physiologist, Wash. 9, 25.

Knobil, E, \& Iotchkiss, J. (I 964). A. Rev. Physiol. 26, 47.

Knopf, R. F., Conn, J. W., Floyd, J. C. Jr, Fajans, S. S., Rull, J. A., Guntsche, E. M. \& Thiffault, C. A. (1966). Trans. Ass. Am. Physns 79, 312.

Korner, A. (I964). Biochem. F. 92, 449.

Korner, A. (1968). Ann. N.Y. Acad .Sci. 148, 408.

Kostyo, J. L. (1964). Endocrinology 75, $\mathrm{Ir}_{3}$.

Kostyo, J. L. (1968). Ann. N.Y. Acad. Sci. 148, 389.

Kostyo, J. L. \& Knobil, E. (1959). Endocrinology 65, 395.

Kostyo, J. \& Rillema, J. A. (I97I). Endocrinology 88, ro54.

Manchester, K. L. (r97o). In Mammalian Protein Metabolism Vol. 4, p. 229 [H. N. Munro, editor]. New York \& London: Academic Press.

Manchester, K. L. \& Young, F. G. (1959). F. Endocr. 18, 38 I.

Milner, R. D. G. (1970). Mem. Soc. Endocr. r8, r9r.

Vilner, R. D. G. (I971). Pediat. Res. 5, 33.

Mönckeberg, F., Donoso, G., Oxman, S., Pak, N. \& Meneghello, J. (1963). Pediatrics, Springfield 3 I, 58.

Mulinos, M. \& Pomerantz, L. (1940). F. Nutr. 19, 493.

Munro, H. N. (editor) (1970). Mantmalian Protein Metabolism Vol. 4. New York \& London: Academic Press.

Pecile, A. \& Müller, E. E. (editors) (I968). Growth Flormone. (Int. Congr. Ser. no. 158). Amsterdam: Excerpta Medica Foundation.

Pecile, A. \& Müller, E. E. (editors) (1972) Growth and Growth Hormone. (Int. Congr. Ser. no. 244.) Amsterdam: Excerpta Medica Foundation.

Pimstone, B., Barbezat, G., Hansen, J. D. L. \& Murray, P. (1967). Lancet ii, I333.

Pimstone, B. L., Barbezat, G., Hansen, J. D. L. \& Murray, P. (1968). Am. F. clin. Nutr. 2 I, 482.

Pronczuk, A. W., Baliga, B. S., 'Triant, J. W. \& Munro, H. N. (r968). Biochim. biophys. Acta 157, 204,

Randle, P. J., Garland, P. B., Hales, C. N., Newsholme, E. A., Denton, R. M. \& Pogson, C. I. (Ig66). Recent Prog. Form. Res, 22, I. 
Reeds, P. J., Munday, K. A. \& Turner, M. R. (I971). Biochem. J. I25, 5 I5.

Russell, J. A. (r951). Endocrinology 49, 99.

'Tata, J. R. (1970). In Biochemical Actions of Hormones p. 89 [G. Litwack, editor]. New York \& London: Academic Press.

Turner, M. R., Reeds, P. J. \& Munday, K. A. (197I). Excerpta Med. int. Congr. Ser. 236, 40.

Waterlow, J. C. \& Alleyne, G. A. O. (1971). Adv. Protein Chem. 25, 117.

Widdowson, E. M. \& McCance, R. A. (rg63). Proc. R. Soc. B. 158, 329.

Wool, I. G., Castles, J. J. \& Moyer, A. N. (1965). Biochim. biophys. Acta. 107, 333.

Wool, I. G., Stirewalt, W. S., Kurihara, K., Low, R. B., Bailey, P. \& Oyer, D. (1968). Recent Prog. Horm. Res. 24, I 39 .

Young, V. R. \& Alexis, S. D. (1968). 7. Nutr. 96, 255. 